\title{
Preliminary analysis of the proteolytic enzymes IN THE EXCRETORY-SECRETORY PRODUCTS OF THE ADULT STAGES OF THE DOG HOOKWORM UNCINARIA STENOCEPHALA
}

\author{
KOTOMSKI G.* \& WEDRYCHOWICZ H.*
}

\section{Summary :}

The paper describes an introductory characterisation of proteinases present in the excretory-secretory products (ESP) of adult Uncinaria stenocephala. In SDS-PAGE gelatine substrate gels ESP resolved as a six bands of proteolytic activity, with a molecular weight of 182, 159,98,50,39 and $26 \mathrm{kDa}$. The 98 and $39 \mathrm{kDa}$ components were serine proteinases. The $50 \mathrm{kDa}$ band was sensitive to a metalloproteinase inhibitor. The $26 \mathrm{kDa}$ component was highly sensitive to cysteine proteinase inhibitors and was also partially inhibited in the presence of EDTA. The bands of 182 and $159 \mathrm{kDa}$ were sensitive to a $\mathrm{Zn}$ metalloproteinase inhibitor.

The enzymes present in ESP showed the highest proteolytic activity at $\mathrm{pH}$ 8-9. Quantitative analysis revealed maximum proteolytic activity of the polypeptides of 159 and $182 \mathrm{kDa}$ at $\mathrm{pH} 7 ; 98$ and $26 \mathrm{kDa}$ at $\mathrm{pH} 8$ while the $50 \mathrm{kDa}$ and $39 \mathrm{kDa}$ components showed the highest activity at $\mathrm{pH} 9$.

KEY WORDS : hookworms, excretory-secretory products, proteinases, Uncinaria stenocephala.

\section{INTRODUCTION}

N ematodes release a variety of proteins with enzymatic properties which, in vivo, are believed to play important roles in the hostparasite relationship. Among the specific functions attributed to the excretory-secretory products (ESP) of nematodes are invasion and migration through host tissues, facilitation of feeding and evasion of host immune responses (Tort et al., 1999). Some proteinases secreted by nematodes have been shown to be inhibited by host antibodies. This is particularly important because it indicates that proteinases of parasite origin constitute targets for the host's immune responses and suggests a way through which immunotherapeutic intervention may protect the host from disease (Tort et al., 1999). Uncinaria stenocephala is a canine hookworm which is prevalent in dogs all over the world (Arene, 1984;

\footnotetext{
* Department of Parasitology, Faculty of Veterinary Medicine, Warsaw Agricultural University, Grochowska 272, 03-849 Warsaw, Poland. Correspondence: $\mathrm{H}$. Wedrychowicz.

Tel./Fax: +48228101851.

E-mail: Wedrychowicz@alpha.SGGW.waw.pl
}

Résumé : ÉTUDE PRÉLIMINAIRE DES CARACTÉRISTIQUES DES PROTÉASES PRÉSENTES DANS LES PRODUITS D'EXCRÉTION-SÉCRÉTION D'UNCINARIA STENOCEPHALA ADULTE

Uncinaria stenocephala est un parasite des canidés appartenant à la famille des ankylostomes. On ignore toujours la composition et la fonction des produits d'excrétion-sécrétion (ESP). Cet essai démontre les caractéristiques préliminaires des protéases présentes dans les ESP d'U. stenocephala adulte.

En utilisant la méthode de l'électrophorèse SDSPAGE, on a découvert six protéines présentant des activités protéolytiques différenciées, de masse moléculaire: 182, 159,98,50, 39 et $26 \mathrm{kDa}$ dans le gel-substrat. Les épreuves avec les inhibiteurs spécifiques des protéases ont démontré que les composants de masse 98 et 39 kDa appartiennent aux protéases à sérine. La bande $50 \mathrm{kDa}$ a des propriétés de métalloprotéase. La bande 26 kDa démontre des caractères de protéase à cystéine. Les composants 182 et 159 semblent être des métalloprotéases à zinc. Les enzymes découvertes dans les ESP montrent une plus grande activité à $\mathrm{pH}$ 8-9.

MOTS CLÉS : ankylostome, produits d'excrétion-sécrétion, protéases, Uncinaria stenocephala.

Blake \& Overend, 1982; Gorski et al., 1996; Vanparijs et al., 1991). Attempts to understand a molecular pathobiology of hookworm infections have largely concentrated on Ancylostoma caninum in dogs and on the human parasites (Brown et al., 1995; Hotez et al., 1995; Furmidge et al., 1995; Pritchard et al., 1990). In contrast, $U$. stenocephala has received scarce attention and very little is known about molecular interactions in this hostparasite relationship, including enzymes secreted by the parasite. In this report we describe the range of proteolytic activities present in the ESP of adult U. stenocephala and we provide a preliminary characterization of the principal enzymes involved.

\section{MATERIAL AND METHODS}

\section{COLLECTION OF THE EXCRETORY-SECRETORY PRODUCTS (ESP)}

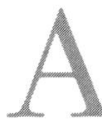
dult nematodes were isolated from the intestines of experimentally infected dogs, washed extensively in $0.15 \mathrm{M}$ sodium chloride containing $100 \mathrm{i} . \mathrm{u} / \mathrm{ml}$ penicillin and $100 \mu \mathrm{g} / \mathrm{ml}$ streptomycin and 
then left over a period of $3 \mathrm{~h}$ at $37^{\circ} \mathrm{C}$ in RPMI 1640 containing $100 \mathrm{i} . \mathrm{u} . / \mathrm{ml}$ penicillin and $100 \mu \mathrm{g} / \mathrm{ml}$ streptomycin in order to permit loss of any remaining host tissues from the worms' intestines (Brown et al., 1995). Following this "cleaning" period adult worms were cultured in sterile RPMI 1640, enriched with antibiotics (as above), for a further $24 \mathrm{~h}$ at $37^{\circ} \mathrm{C}$. As assessed by monitoring worm motility, the parasites remained viable in culture. The culture fluid containing ESP was dialysed against distilled water $\mathrm{pH} 7.0$, freeze dried and reconstituted in distilled water prior to use (Brown et al., 1995)

\section{MEASUREMENT OF PROTEINASE ACTIVITY}

Proteinases were detected following their electrophoretic separation using gelatin-SDS PAGE assay system (Hotez et al., 1990; Hawdon et al., 1995) which consisted of $12 \% \mathrm{w} / \mathrm{v}$ acrylamide gels containing $0.2 \% \mathrm{w} / \mathrm{v}$ gelatin, TRIS- $\mathrm{HCl}$ buffer $\mathrm{pH} 8.8$ and $0.1 \%(\mathrm{w} / \mathrm{v})$ SDS Typically $10 \mu \mathrm{g}$ of total protein was separated per lane of gels. Following electrophoresis gels were incubated at $25^{\circ} \mathrm{C}$ in $25 \% \mathrm{v} / \mathrm{w}$ Triton $\mathrm{X}-100$ for $1 \mathrm{~h}$ and then in glycine buffer $(0.05 \mathrm{M}, \mathrm{pH}$ 6-8) with or without proteinase inhibitors at $37^{\circ} \mathrm{C}$.

\section{CHARACTERIZATION OF PROTEINASES USING PROTEINASE INHIBITORS}

The proteinase inhibitors were obtained from SigmaAldrich Germany and applied at concentrations reported by Kumar \& Pritchard (1992), Hawdon et al. (1995) and Cordova et al. (1997). The inhibitors used were as follows: 1,10 phenanhtroline ( $2 \mathrm{mM}$; Zn-metalloproteinase inhibitor); ethylendiaminetetracetic acid (EDTA; $10 \mathrm{mM}$; metalloproteinase inhibitor); phenylmethanesulphonyl fluoride (PMSF; $10 \mathrm{mM} \& 1 \mathrm{mM}$, serine proteinase inhbibitor); pepstatin ( $70 \mu \mathrm{M}$, aspartic proteinase inhibitor),

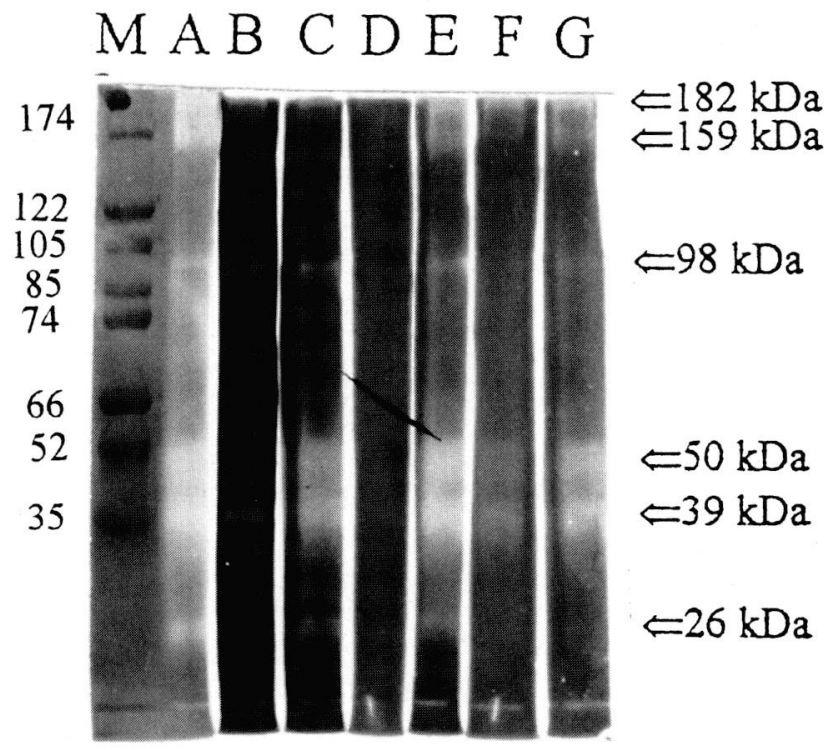

$\mathrm{N}$-ethylmaleimide (NEM; 10 or $5 \mathrm{mM}$, cysteine proteinase inhibitor); iodoacetamide (IA; $5 \mathrm{mM}$, cysteine proteinase inhibitor). The assays were conducted at $\mathrm{pH}$ 7.0.

\section{ESTIMATION OF THE PH OPTIMA FOR PROTEINASE ACTIVITY}

Assays were conducted with a $\mathrm{pH}$ range from 3 to 11 . After electrophoresis, gels were immersed in different buffers prepared as described by Dowd et al. (1994) and incubated at $37^{\circ} \mathrm{C}$. After the incubation, the gels were scanned then area of proteolysis were measured and compared using a computer program "DiversitiOne ${ }^{\mathrm{TM}}$ " version 1.3 ( $p d i$ ). The programme calculates the proteolytic activity index by measuring the area and intensity of substrate degradation.

\section{RESULTS}

ix bands of proteolysis at 182, 159, 98, 50, 39 and $26 \mathrm{kDa}$ were observed in substrate gels incubated without inhibitors (Fig. 1, lane A). Several proteinase inhibitors affected the proteolysis associated with components of differing molecular weight (Fig. 1B-G, Table I). The 182, 159, 50 and $26 \mathrm{kDa}$ bands were absent from gels incubated in the presence of EDTA (metallopro-

\begin{tabular}{|c|c|c|c|c|c|c|}
\hline \multirow[b]{2}{*}{$\begin{array}{l}\text { Proteinase } \\
\text { inhibitor }\end{array}$} & \multicolumn{6}{|c|}{ Proteolytic activity } \\
\hline & $\begin{array}{l}182 \\
\mathrm{kDa}\end{array}$ & $\begin{array}{l}159 \\
\mathrm{kDa}\end{array}$ & $\begin{array}{c}98 \\
\mathrm{kDa}\end{array}$ & $\begin{array}{c}50 \\
\mathrm{kdA}\end{array}$ & $\begin{array}{c}39 \\
\mathrm{kDa}\end{array}$ & $\begin{array}{c}26 \\
\mathrm{kDa}\end{array}$ \\
\hline $\begin{array}{l}\text { No inhibitor } \\
\text { EDTA }\end{array}$ & + & + & + & + & + & + \\
\hline $\begin{array}{l}10 \mathrm{mM} \\
1,10 \text { phenathroline }\end{array}$ & - & - & + & - & + & $+1-$ \\
\hline $\begin{array}{l}2 \mathrm{mM} \\
\text { PMSF }\end{array}$ & - & - & + & + & + & + \\
\hline $\begin{array}{r}10 \mathrm{mM} \\
1 \mathrm{mM}\end{array}$ & $\begin{array}{l}- \\
+\end{array}$ & $\begin{array}{l}- \\
+\end{array}$ & $\begin{array}{l}- \\
-\end{array}$ & $\begin{array}{l}- \\
+\end{array}$ & - & $\begin{array}{l}- \\
+\end{array}$ \\
\hline Pepstatin & & & & & & \\
\hline $\begin{array}{l}70 \mathrm{~mm} \\
\text { N-ethylmaleimide }\end{array}$ & + & + & + & + & + & + \\
\hline $\begin{array}{r}10 \mathrm{mM} \\
5 \mathrm{mM}\end{array}$ & $\begin{array}{l}+ \\
+\end{array}$ & $\begin{array}{c}+/- \\
+\end{array}$ & $\begin{array}{c}+/- \\
+\end{array}$ & $\begin{array}{l}+ \\
+\end{array}$ & $\begin{array}{l}+ \\
+\end{array}$ & $\begin{array}{l}- \\
+\end{array}$ \\
\hline Iodoacetamide & & & & & & \\
\hline $5 \mathrm{mM}$ & + & + & + & + & + & + \\
\hline
\end{tabular}

Table I. - Sensitivity of proteinases secreted by adult $U$. stenocephala to inhibitors.

Fig. 1. - Characterization of gelatinolytic proteinases in the excretory-secretory products (ESP) of adult Uncinaria stenocephala using proteinase inhibitors.

Lanes: M - molecular weight markers ( $\mathrm{kDa}$ ); A - the SDS-PAGE profile of gelatinolytic proteinases in $U$. stenocephala ESP (no inhibitor); $\mathrm{B}$ - metalloproteinase inhibitor (EDTA); C - Zn-metalloproteinase inhibitor (1,10-phenanthroline); D - serine proteinase inhibitor (phenylmethanesulphonyl fluoride); $\mathrm{E}$ - aspartic proteinase inhibitor (pepstatin); F - cysteine proteinase inhibitor ( $N$-ethylmaleimide); $\mathrm{G}$ - cysteine proteinase inhibitor (iodoacetamide). 
teinase inhibitor, Fig.1B) while $\mathrm{Zn}$ metalloproteinase inhibitor (1,10 phenanthroline) caused deprivation of the proteolytic activity of 182 and $159 \mathrm{kDa}$ components (Fig. 1C). In the presence of $10 \mathrm{mM}$ PMSF only 182 and 159 bands exhibited a weak activity (Fig. 1D). However, when the incubation buffer contained $1 \mathrm{mM}$ PMSF only 98 and $39 \mathrm{kDa}$ bands were inhibited (Table I). None of the ESP proteinases were affected by the aspartic proteinase inhibitor (Fig. 1E). $10 \mathrm{mM} \mathrm{NEM}$ blocked the enzymatic activity of the $26 \mathrm{kDa}$ and attenuated $159 \mathrm{kDa}$ and $98 \mathrm{kDa}$ bands (Fig. 1F). When lower concentration of the inhibitor was used only the proteolytic activity of $26 \mathrm{kDa}$ declined (Fig. 1G, Table I) The optimal $\mathrm{pH}$ conditions for proteolysis by ESP were evaluated and quantitative analysis revealed maximum proteolytic activity of the polypepetides of 182 and $159 \mathrm{kDa}$ at $\mathrm{pH} 7.0$; those of 98 and $26 \mathrm{kDa}$ at $\mathrm{pH} 8$ while the $50 \mathrm{kDa}$ and $39 \mathrm{kDa}$ components showed higher activity at $\mathrm{pH}$ 9. No proteolytic activity was observed at pH 10 and 11. The results are shown in Figure 2.

\section{DISCUSSION}

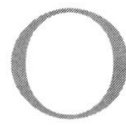

ur experiments demonstrated that excretorysecretory products of adult $U$. stenocephala include a heterogeneous mixture of proteolytic activities. To our knowledge, there have been no reports on proteinases of $U$. stenocephala. Reports concerning proteolytic activities found in the ESP of other hookworms are limited and among those which have been described so far, differences in structure and function have been reported (Dowd et al., 1994; Hotez et al., 1985; Kumar \& Pritchard, 1992; Pritchard et al., 1990; Tort et al., 1999).

Results obtained using various proteinase inhibitors strongly suggested lack of aspartic proteinases in the ESP of adult $U$. stenocephala. The 26, 50, 159 and $182 \mathrm{kDa}$ components lost their proteolytic activities in the presence of EDTA (metalloproteinase inhibitor), while 1,10 phenathroline which is a strong $\mathrm{Zn}$ atoms chelator, inhibited only 159 and $182 \mathrm{kDa}$ bands. Because EDTA is much less effective against $\mathrm{Zn}$ and more effective in chelating $\mathrm{Ca}$, the results seem to suggest that the 159 and $182 \mathrm{kDa}$ bands contain $\mathrm{Zn}$ metalloproteinases, whereas the 50 and $26 \mathrm{kDa}$ components include enzymes utilising $\mathrm{Ca}$ or another cofactor (Bond \& Butler, 1987). An activity of metalloproteinases has been detected in ES products of other hookworm species. For instance, Hawdon et al. (1995) found metalloproteinases of 50 and $90 \mathrm{kDa}$ in ES products of $A$. caninum. Diverse results were obtained in the present experiment using serine proteinase inhibitor (PMSF). We initially used the $10 \mathrm{mM}$ concentration of PMSF since

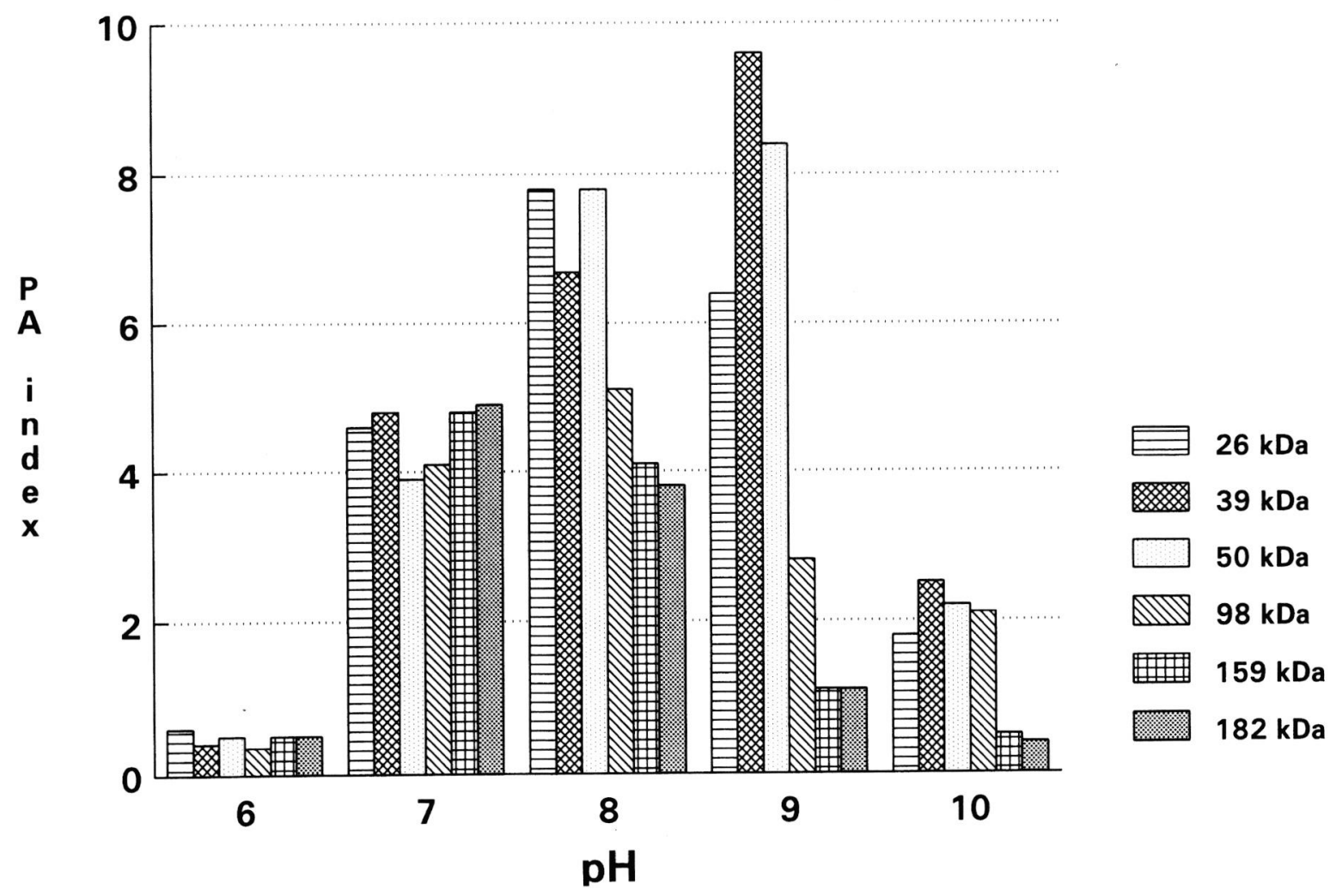

Fig. 2. - Results of computer analysis of effects of $\mathrm{pH}$ on proteolytic activity of enzymes present in excretory-secretory products of adult U. stenocephala $\mathrm{PA}=$ proteolytic activity. 
Kumar \& Pritchard (1992) reported that only $10 \mathrm{mM}$ but not $1 \mathrm{mM}$ or $5 \mathrm{mM}$ PMSF inhibited ESP proteinases of Necator americanus. However, the $10 \mathrm{mM}$ PMSF blocked entirely the proteolytic activity of ESP of $U$. stenocephala. Therefore we repeated experiments using $1 \mathrm{mM}$ PMSF and found that proteolytic activity of only 39 and $98 \mathrm{kDa}$ components was inhibited. The complete inhibition of proteolytic activity of the ESP observed in presence of $10 \mathrm{mM}$ PMSF resulted possibly from a non-specific inhibition (Bond \& Butler, 1987). Similarly, a non-specific inhibition has probably also occurred in test using $10 \mathrm{mM}$ NEM. The $10 \mathrm{mM}$ NEM affected proteolytic activity of three components (159, 98 and $26 \mathrm{kDa}$ ) while $5 \mathrm{mM}$ concentration of the inhibitor blocked activity only of the $26 \mathrm{kDa}$ component. The $26 \mathrm{kDa}$ band was also sensitive to IA and EDTA inhibition. On the strength of the fact that both IA and NEM, which are cysteine proteinase inhibitors, caused similar effect and that EDTA is a strong metal chelator, we can tentatively conclude that the $26 \mathrm{kDa}$ component belongs to cysteine class of proteinases and possesses a metal cofactor. The metal ions are often required for the activity of other than metalloproteinases classes (Bond \& Butler, 1987). The proteolytic activity of the $26 \mathrm{kDa}$ component was most pronounced at $\mathrm{pH} 8$ although a clear activity was also observed at $\mathrm{pH} 7$ and 9. Similar $\mathrm{pH}$ values have been reported by Dowd et al., (1994) and Brown et al. (1995) for cysteine proteinases secreted by adult $A$. caninum. The results of our preliminary analysis of the ESP of adult $U$. stenocephala suggest that serine and metalloproteinases account for the most pronounced proteolytic activity in the ESP of the nematode. However, further investigations of the proteinases released by $U$. stenocephala are needed in order to characterise their role in pathogenesis and immunobiology of the nematode infection.

\section{ACKNOWLEDGEMENTS}

This work was supported by Polish Committee for Scientific Research (Grant KBN Nr 5 PO6K021 13).

\section{REFERENCES}

ARENE F.O. Prevalence of toxocariasis and echinococcosis among dogs in the Niger Delta. Journal of Tropical Medicine and Hygiene, 1984, 87, 207-209.

Blake R.T. \& OverEnd D.J. The prevalence of Dirofilaria immitis and other parasites in urban pound dogs in northeastern Victoria. Australian Veterinary Journal, 1982, 58, 111-114.

BOnd J.S. \& Butler P.E. 1989. Intracellular proteases. Annual Review of Biochemistry, 1987, 56, 333-364.
Brown A., Burleigh J.M., Billet E.E. \& Pritchard D.I. An initial characterization of the proteolytic enzymes secreted by the adult stage of the human hookworm Necator americanus. Parasitology, 1995, 110, 555-563.

Cordova M., Herrera P., Nopo L., Bellatin J., Naquira C., Guerra H. \& Espinoza J.R. Fasciola hepatica cysteine proteinases: immunodominant antigens in human fasciolasis. American Journal of Tropical Medicine and Hygiene, 1997, 57, 660-666.

Dowd A.J., Dalton J.P., Loukas A.C., Prociv P. \& Brindley P.J. Secretion of cysteine proteinase activity by the zoonotic hookworm Ancylostoma caninum. American Journal of Tropical Medicine and Hygiene, 1994, 51, 341-347.

Furmidge B.A., Horn L.A. \& Pritchard D.I. The anti-haemostatic strategies of the human hookworm Necator americanus. Parasitology, 1995, 112, 81-87.

GóRSKi P., BADOwsKa M. \& WedRYCHOWICZ H. Distribution of nematode Uncinaria stenocephala in dogs from Warsaw region. Wiadomości Parazytologiczne, 1996, 42, 221-227.

Hawdon J.M., Jones B.F., Perregaux M.A. \& Hotez P.J. Ancylostoma caninum: metalloprotease release coincides with activation of infective larvae in vitro. Experimental Parasitology, 1995, 80, 205-211.

Hotez P.J., Trang N.L., McKerrow J.H. \& Cerami A. Isolation and characterization of a proteolytic enzyme from the adult hookworm Ancylostoma caninum. Journal of Biological Chemistry, 1985, 260, 7343-7348.

Hotez P., Haggerty J., Hawdon J., Milstone L., Gamble H.R., SCHAD G. \& Richards F. Metalloproteases of infective Ancylostoma hookworm larvae and their possible functions in tissue invasion and ecdysis. Infection and Immunity, 1990, 58, 3883-3892.

Hotez P.J., Hawdon J.M., Cappello M., Jones B.F. \& PritCHARD D.I. Molecular pathobiology of hookworm infection. Infectious Agents and Disease, 1995, 4, 71-75.

Kumar S. \& PRITChard D.I. The partial characterization of proteases present in the excretory-secretory products and exsheathing fluid of the infective (L3) larva of Necator americanus. International Journal for Parasitology, 1992, 22, 563-572.

Pritchard D.I., McKean P.G. \& Schad G.A. An Immunological and biochemical comparison of hookworm species. Parasitology Today, 1990, 6, 154-156.

Tort J., Brindley P.J., Knox D, Wolfe K.H. \& Dalton J.P. Proteinases and associated genes of parasitic helminths. Advance in Parasitology, 1999, 43, 162-266.

Vanpariss O., Hormans L. \& VAN DER FlaEs L. Helminth and protozoan parasites in dogs and cats in Belgium. Veterinary Parasitology, 1991, 38, 67-73.

Reçu le 10 avril 2000 Accepté le 21 septembre 2000 